\title{
Comparative analysis of two different Turkish hospital reports on polytrauma patients with thoracic trauma
}

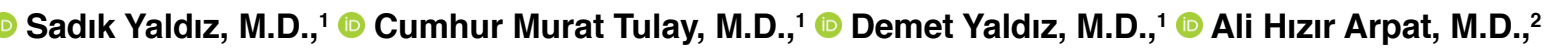 \\ (1) Abdülkerim Bayülgen, M.D., ${ }^{3} \odot$ Mehmet Gökhan Pirzirenli, M.D., ${ }^{4} \odot$ Cenk Balta, M.D. ${ }^{2}$
}

\author{
1'Department of Thoracic Surgery, Manisa Celal Bayar University Faculty of Medicine, Manisa-Turkey \\ ${ }^{2}$ Department of Thoracic Surgery, Şanlıurfa Training and Research Hospital, Şanlıurfa-Turkey \\ ${ }^{3}$ Department of Thoracic Surgery, Mersin University Faculty of Medicine, Mersin-Turkey \\ ${ }^{4}$ Department of Thoracic Surgery, Ondokuz Mayıs University Faculty of Medicine, Samsun-Turkey
}

\begin{abstract}
BACKGROUND: The present study aims to assess whether there are any differences in the management and outcome of polytrauma patients with thoracic trauma in trauma units of two different hospitals in the same country; one hospital is near the Syrian border.

METHODS: A retrospective analysis (January 2012 to January 2014) of 348 polytrauma casualties with thoracic trauma from Manisa Celal Bayar University Hospital $(\mathrm{MH})$ were compared according to age, gender, mechanism of injury, associated injuries, abbreviated injury scale (AIS), injury severity score (ISS), treatment modalities, and mortality with 917 patients of Şanlıurfa Training and Research Hospital (SH) registry (near the Syrian border).
\end{abstract}

RESULTS: Of the 348 patients in the $\mathrm{MH}, 230(66 \%)$ and of the 917 patients in the $\mathrm{SH}, 697(76 \%)$ were males ( $\mathrm{p}<0.00 \mathrm{I})$. Mean age was $45.6 \pm 18.3 \mathrm{yrs}$ in the $\mathrm{MH}$ group and $26.4 \pm 22.4 \mathrm{yrs}$ in the $\mathrm{SH}$ group $(\mathrm{p}<0.00 \mathrm{I})$. The $\mathrm{SH}$ patients had a larger proportion of stab wounds ( $\mathrm{MH}$; $9 \%$ vs. $\mathrm{SH}$; $17 \%$, $\mathrm{p}<0.05)$, gunshot injuries $(\mathrm{MH} ; 5 \%$ vs. $\mathrm{SH}$; $18 \%$, $\mathrm{p}<0.05)$, higher mean ISS (MH; $30.2 \pm 8.4$ vs. SH; $42.8 \pm 10.2, \mathrm{p}<0.00 \mathrm{I})$, and increased mortality $(\mathrm{MH} ; 2.6 \%$ vs. SH; II.I\%, $\mathrm{p}<0.00 \mathrm{I})$. AIS ${ }_{\text {abdomen }}$ was the highest component in the $\mathrm{SH}$ registry $\left(\mathrm{AIS}_{\text {abdomen }}=4.8 \pm 0.7\right)$, whereas AIS extremities were the highest component in the MH registry $\left(\mathrm{AIS}_{\text {extremities }}=3.6 \pm 0.2\right)$.

CONCLUSION: Significantly different demographic features, mechanisms of injury, worse outcomes and higher mortality rates in $\mathrm{SH}$ demonstrate and reflect the surgical challenges depending on the combat environment. Two hospitals in Turkey, one seemingly adjacent to a war zone and another with the more standard civilian experience highlight the impact of the Syrian conflict on the Turkish healthcare system.

Keywords: Associated injuries; polytrauma; thoracic trauma.

\section{INTRODUCTION}

Despite global efforts, chest trauma still constitutes the third most common cause of death after abdominal injury and head trauma in polytrauma patients. ${ }^{[1]}$ This means chest traumas comprise approximately $10-15 \%$ of all traumas and directly account for approximately $20-25 \%$ of all deaths in polytrauma patients. ${ }^{[2,3]}$ Although there are many publications regarding chest trauma, different studies have indicated signif- icant differences in their morbidity and mortality. Given the differences in the severity and complexity of these injuries, clinicians need to reveal all the possible injuries as quickly as possible. Management of thoracic trauma patients also can sometimes be more different and challenging due to geographic localisation. Knowledge of the common mechanisms and patterns of injury are necessary to predict, treat and prevent traumatic injury.

Cite this article as: Yaldız S, Tulay CM, Yaldız D, Arpat AH, Bayülgen A, Pirzirenli MG, et al. Comparative analysis of two different Turkish hospital reports on polytrauma patients with thoracic trauma. Ulus Travma Acil Cerrahi Derg 2021;27:55-60.

Address for correspondence: Sadık Yaldız, M.D.

Celal Bayar Üniversitesi Tıp Fakültesi, Göğüs Cerrahisi Anabilim Dalı, Manisa, Turkey

Tel: +90 236 - 2338586 E-mail: msyaldiz@gmail.com

Ulus Travma Acil Cerrahi Derg 2021;27(I):55-60 DOI: 10.14744/tjtes.2020.80I95 Submitted: 16.06.20I9 Accepted: 23.03.2020 Online: 09.12.2020

Copyright 2021 Turkish Association of Trauma and Emergency Surgery 
Accordingly, we proposed a study that focused on polytrauma patients with thoracic trauma and associated injuries on the thoracic surgery unit of the Manisa Celal Bayar University Hospital (located in the Aegean region of the Anatolia) and Şanlıurfa Training and Research Hospital (located in the Southeast region of Anatolia near the Syrian border) over a three-year period. We selected Şanlıurfa Training and Research Hospital because most of the victims of the Syrian civil war were transferred to this hospital. Besides, we also sought to identify the differences in epidemiology, characteristics, incidence and management of these patients, thus reminding surgeons to pay more attention to the countries' geographic and demographic features.

\section{MATERIALS AND METHODS}

The medical records of polytrauma patients with thoracic trauma of aforementioned hospitals between January 2012 and January 2014 were retrospectively reviewed. AIS scales and Injury severity scores of all patients were calculated. ${ }^{[4,5]}$ Patients who were in a state of cardiac arrest or found dead, AIS $_{\text {chest }}$ I, AIS ${ }_{\text {chest }}$, and ISS $<16$ were not included in this study. Polytrauma was defined as stated by the new Berlin definition.

${ }^{[6]}$ Cases with AIS $\geq 3$ for two or more body regions and having at least one or more variables from these five physiologic parameters (hypotension-unconsciousness-acidosis-coagulopathy-age $\geq 70$ years) were included in this study. ${ }^{[6]}$ Collected data were compared according to age, gender, mechanism of injury, ISS, AIS, associated injuries, operative procedures and rate of mortality. For the categorical variables, chi-squared test $\left(\chi^{2}\right)$, and for comparing the independent variables, a two-sample t-test with a $95 \%$ confidence interval was used. P-values $<0.05$ were denoted significant. All procedures performed in this study were in accordance with the ethical standards of both hospitals and with the 2013 Helsinki declaration. Our hospital's Institutional Review Board approved this study (date: 13.06.2019, no: 33619151/2185). Informed consent was waived since this was a retrospective study.

\section{RESULTS}

Three hundred and forty-eight charts from $\mathrm{MH}$ were reviewed with nine-hundred and seventeen charts from the $\mathrm{SH}$ registry. The mean age of patients was $45.6 \pm 18.3 \mathrm{yrs}$, with 230 male $(66 \%)$ in the $\mathrm{MH}$ and $26.4 \pm 22.4 \mathrm{yrs}$, with 697 male $(76 \%)$ in the $\mathrm{SH}$ group. There was a male preponderance in the $\mathrm{SH}$ group, and patients were significantly younger $(p<0.00 \mathrm{I})$. The predominant mechanism of injury was blunt trauma in each hospital record $(\mathrm{MH}: \mathrm{n}=288 ; 83 \%$ vs. $\mathrm{SH}$ : $\mathrm{n}=573 ; 63 \%$ ) but the percentage of patients sustaining penetrating chest trauma was significantly higher in the $\mathrm{SH}$ group $(n=344 ; 37 \%$ vs. $n=60 ; 17 \% ; p<0.00$ I) (Table I). Statistically significant differences were found in stab wounds $(\mathrm{MH} ; 9 \%$ vs. $\mathrm{SH} ; 17 \% ; \mathrm{p}<0.005)$ and gunshot injury rates $(\mathrm{MH} ; 5 \%$ vs. $\mathrm{SH} ; 18 \% ; \mathrm{p}<0.005)$. Motor vehicle crash was most common in both hospital registries, accounting for $53 \%$ of $\mathrm{MH}$ versus
Table I. Comparison of demographic and clinical variables between $\mathrm{MH}$ and $\mathrm{SH}$

\begin{tabular}{|c|c|c|c|}
\hline & MH & SH & $\mathbf{p}$ \\
\hline Number of the patients & 348 & 917 & \\
\hline Mean age (years $\pm S D$ ) & $45.6 \pm 18.3$ & $26.4 \pm 22.4$ & $<0.001^{a}$ \\
\hline \multicolumn{4}{|l|}{ Sex, n (\%) } \\
\hline Female & 118 (34) & $220(24)$ & \\
\hline Male & $230(66)$ & $697(76)$ & $<0.001^{\mathrm{b}}$ \\
\hline ISS ( $( \pm S D)$ & $30.2 \pm 8.4$ & $42.8 \pm 10.2$ & $<0.00 I^{a}$ \\
\hline AIS chest $( \pm S D)$ & $3.4 \pm 0.9$ & $3.9 \pm 0.2$ & $<0.00 I^{a}$ \\
\hline \multicolumn{4}{|l|}{ Type of the injury, $n$ (\%) } \\
\hline Blunt injury & $288(83)$ & $573(63)$ & $<0.001^{b}$ \\
\hline Penetrating injury & $60(17)$ & $344(37)$ & \\
\hline Mortality, n (\%) & $9(2.6)$ & $102(1 \mathrm{I} .1)$ & $<0.00 I^{b}$ \\
\hline
\end{tabular}

a: t-test; b: Chi-Squared test. SD: Standard deviation; ISS: Injury severity score; AIS: Abbreviated injury scale; $\mathrm{MH}$ : Manisa Celal Bayar University Hospital; $\mathrm{SH}$ : Şanlıurfa Training and Research Hospital.

Table 2. Mechanisms of injury

\begin{tabular}{|c|c|c|c|c|c|}
\hline & \multicolumn{2}{|c|}{ MH } & \multicolumn{2}{|c|}{ SH } & \multirow[t]{2}{*}{$\mathbf{p}^{\mathbf{a}}$} \\
\hline & $\mathbf{n}$ & $\%$ & $\mathbf{n}$ & $\%$ & \\
\hline Motor vehicle crash & 184 & 53 & 338 & 37 & $<0.05$ \\
\hline Pedestrian & 52 & 15 & 101 & II & $*$ \\
\hline Motorcycle/bicycle & 38 & II & 83 & 9 & $*$ \\
\hline Gunshot injuries & 17 & 5 & 165 & 18 & $<0.05$ \\
\hline Stab wound & 32 & 9 & 156 & 17 & $<0.05$ \\
\hline Fall down & 14 & 4 & 28 & 3 & $*$ \\
\hline Explosion & 4 & I & 37 & 4 & $<0.05$ \\
\hline Other & 7 & 2 & 9 & I & $*$ \\
\hline
\end{tabular}

a: Chi-Squared test. MH: Manisa Celal Bayar University Hospital; SH: Şanlurfa Training and Research Hospital.

Table 3. Abbreviated injury scales (AIS) of injury patterns

\begin{tabular}{lcccc}
\hline & MH & SH & $\mathbf{p}^{\mathbf{a}}$ & $\begin{array}{c}95 \% \text { confidence } \\
\text { interval }\end{array}$ \\
\hline AIS $_{\text {chest }}$ & $3.4 \pm 0.9$ & $3.9 \pm 0.2$ & $<0.001$ & $0.44-0.56$ \\
AIS $_{\text {abdomen }}$ & $3.3 \pm 0.4$ & $4.8 \pm 0.7$ & 0.197 & $0.79-3.79$ \\
AIS $_{\text {head }}$ & $1.7 \pm 0.7$ & $2.4 \pm 0.7$ & 0.195 & $0.36-1.76$ \\
AIS $_{\text {extremities }}$ & $3.6 \pm 0.2$ & $4.1 \pm 0.4$ & $<0.001$ & $0.46-1.76$ \\
\hline a: t-test. & & & & \\
\end{tabular}

$37 \%$ in the $\mathrm{SH}$. The number of pedestrians comprised the second largest group of trauma patients, being more in the $\mathrm{MH}$ group (15\% vs. II\%). Motorcycle/bicycle accident rates 
Table 4. Pattern of chest injuries

\begin{tabular}{lccccc}
\hline \multirow{2}{*}{ Chest injuries } & \multicolumn{2}{c}{ MH } & & \multicolumn{2}{c}{ SH } \\
\cline { 2 - 3 } \cline { 5 - 6 } & n & $\%$ & & n & $\%$ \\
\hline Rib fracture & 248 & 65 & & 342 & 37 \\
Pulmonary contusion & 143 & 37 & & 269 & 29 \\
Pneumothorax & 91 & 24 & 321 & 35 \\
Hemothorax & 68 & 18 & 253 & 28 \\
Hemopneumothorax & 62 & 18 & 183 & 20 \\
Subcutaneous emphysema & 81 & 21 & 201 & 22 \\
Mediastinal emphysema & 19 & 5 & 83 & 9 \\
Flail chest & 27 & 7 & 91 & 10 \\
Ruptured diaphragm & 11 & 3 & 45 & 5 \\
Clavicle fracture & 27 & 7 & 135 & 15 \\
Sternal fracture & 8 & 2 & 46 & 5 \\
Scapular fracture & 23 & 6 & 122 & 13 \\
\hline
\end{tabular}

MH: Manisa Celal Bayar University Hospital; SH: Şanlıurfa Training and Research Hospital.

were nearly equivalent (1 $1 \%$ vs. $9 \%$ ) in the $\mathrm{MH}$ and $\mathrm{SH}$ patient populations (Table 2).

When we looked at the injury pattern, the severity of chest trauma was significantly different between the $\mathrm{MH}$ $\left(\mathrm{AIS}_{\text {chest }}=3.4 \pm 0.9\right)$ and the SH $\left(\mathrm{AIS}_{\text {chest }}=3.9 \pm 0.2\right)$ groups $(p<0.00 \mathrm{I})$. AlS $\mathrm{Abdomen}_{\text {was }}$ the highest component in the $\mathrm{SH}$ registry ( $\mathrm{AIS}$ abdomen $=4.8 \pm 0.7)$ and was significantly different from the $M H\left(\right.$ AlS $\left._{\text {abdomen }}=3.3 \pm 0.4\right)(p=0.197)$, whereas $A I S_{\text {ex }}$ tremities was the highest component in the MH registry ( $\mathrm{AlS}_{\text {ex }}$ tremities $=3.6 \pm 0.2)(p<0.00 \mathrm{I})($ Table 3$)$.

In the pattern of a chest injury, rib fractures comprised $65 \%$ and $37 \%$ of $\mathrm{MH}$ and SH registry, respectively (Table 4). The incidences of pneumothorax, hemothorax and hemopneumothorax were $24 \%, 18 \%$, and $18 \%$ in the $\mathrm{MH}$, and $35 \%, 28 \%$, and $28 \%$ in the SH database. Pulmonary contusion was the most common pulmonary parenchymal injury and was observed in $37 \%$ and $29 \%$ of the $\mathrm{MH}$ and $\mathrm{SH}$ registry. Unstable cases those with flail chest comprised $27(7 \%)$ and 91 (10\%) of the $\mathrm{MH}$ and $\mathrm{SH}$ patients population, respectively. Ten patients (I\%) underwent an emergency department thoracotomy (resuscitative thoracotomy) in the $\mathrm{SH}$ group. The survival rate for these patients was $20 \%$ ( 2 of 10$)$, and 64 patients $(7 \%)$ underwent urgent (nonresuscitative) thoracotomy with a survival rate of $67 \%$ (43 of 64). Emergency department thoracotomy was not performed in an $\mathrm{MH}$ patient population. Eleven patients (3\%) underwent urgent thoracotomy, and the survival rate was $91 \%$ (I0 of II). Regarding treatment, intercostal tube drainage was the mainstay of treatment in $55 \%$ of the $\mathrm{MH}$ cases and late thoracotomy was performed in eight cases (3\%). Chest tube insertion rate was nearly the same in the $\mathrm{SH}$ group (59\%), but late thoracotomy was required in 56 patients $(6 \%)$. Video-assisted thoracoscopic surgery (VATS) was performed in six (1.7\%) of $\mathrm{MH}$ and 15 (1.6\%) of SH cases for various indica-
Table 5. Comparison of concomitant injuries

\begin{tabular}{lcccccc}
\hline & \multicolumn{2}{c}{ MH } & & \multicolumn{2}{c}{ SH } \\
\cline { 2 - 3 } \cline { 5 - 6 } & n & $\%$ & & n & $\%$ \\
\hline Head injuries & 52 & 13 & & 341 & 37 \\
Hepatic injuries & 42 & 11 & & 146 & 16 \\
Splenic injuries & 39 & 10 & & 244 & 27 \\
Stomach perforation & 8 & 2 & & 82 & 9 \\
Colon perforation & 12 & 3 & 75 & 8 \\
Extremity injuries & 56 & 16 & & 351 & 38 \\
Pelvic bone fracture & 50 & 14 & & 139 & 15 \\
Spine injury & 56 & 16 & 230 & 25 \\
\hline
\end{tabular}

MH: Manisa Celal Bayar University Hospital; SH: Şanlıurfa Training and Research Hospital.

Table 6. Distribution of the AIS ${ }_{\text {chest }}$, comparison of the $\mathrm{MH}$ and $\mathrm{SH}$ groups

\begin{tabular}{|c|c|c|c|c|c|}
\hline & \multicolumn{2}{|c|}{ MH } & \multicolumn{2}{|c|}{ SH } & \multirow[t]{2}{*}{$\mathbf{p}^{\mathbf{a}}$} \\
\hline & $\mathbf{n}$ & $\%$ & $\mathbf{n}$ & $\%$ & \\
\hline $\mathrm{AIS}_{\text {chest }} 3$ & 187 & 54 & 282 & 30 & $<0.00$ \\
\hline AIS $_{\text {chest }} 4$ & 108 & 31 & 390 & 43 & \\
\hline AIS $_{\text {chest }} 5$ & 53 & 15 & 245 & 27 & \\
\hline
\end{tabular}

a: Chi-Squared test; MH: Manisa Celal Bayar University Hospital; SH: Şanlıurfa Training and Research Hospital.

tions like removal of a bullet from mediastinum or thorax, for suspected diaphragmatic hernia and removal of the clot.

The most common associated injuries included abdominal injuries $(60 \%)$, followed by extremities $(38 \%)$, head injuries (37\%), spine injury (25\%) and pelvic bone fracture $(15 \%)$ in the SH database (Table 5). Abdominal injury (26\%) was also the leading injury in the $\mathrm{MH}$ group, followed by extremities (16\%), spine injury (15\%), pelvic bone fracture $(14 \%)$ and head injuries (13.5\%). Spleen injury $(n=244 ; 27 \%)$ was the most common intra-abdominal injury, followed by hepatic injury $(n=146 ; 16 \%)$, in the SH database, whereas hepatic injury $(n=42 ; 11 \%)$ was the most common intra-abdominal injury, followed by spleen injury $(n=39 ; 10 \%)$ in the $\mathrm{MH}$ database. $195(21 \%)$ cases in the $\mathrm{SH}$ group and $18(5 \%)$ cases in the $\mathrm{MH}$ group underwent splenectomy and this difference was statistically significant $(p<0.05)$. Laparotomy was performed for hepatic injury in 38 (26\%) of the I46 patients (SH group) and five (12\%) of 42 patients (MH group). This was also statistically significant $(p<0.05)$. The gastrointestinal injury was discovered in $82(9 \%)$ and $75(8 \%)$ of the $\mathrm{SH}$ cases compared to eight (2\%) and 12 (3\%) in the $\mathrm{MH}$ group. In $18 \%$ of the $\mathrm{MH}$ cases, non-thoracic surgical operations had to be performed, whereas it significantly increased to $42 \%$ in the $\mathrm{SH}$ group. 
Table 7. ISS correlation with AIS

\begin{tabular}{lcccc}
\hline ISS & MH & SH & $\mathbf{p}^{\mathrm{a}}$ & $\begin{array}{c}95 \% \text { confidence } \\
\text { interval }\end{array}$ \\
\hline $\mathrm{AIS}_{\text {chest }} 3$ & $25.3 \pm 1.8$ & 30.6 .0 & $<0.001$ & $4.86-5.74$ \\
$\mathrm{AIS}_{\text {chest }} 4$ & $32.4 \pm 4.8$ & $41.8 \pm 8.4$ & $<0.001$ & $8.46-10.34$ \\
$\mathrm{AIS}_{\text {chest }} 5$ & $42.6 \pm 10.1$ & $57.2 \pm 12.7$ & $<0.001$ & $13.1 \mathrm{I}-16.09$ \\
Total $^{3}$ & $30.2 \pm 8.4$ & $42.8 \pm 10.2$ & & \\
\hline
\end{tabular}

a: t-test. ISS: Injury severity score; AIS: Abbreviated injury scale; MH: Manisa Celal Bayar University Hospital; SH: Şanlıurfa Training and Research Hospital.

$\mathrm{AlS}_{\text {chest }}( \pm \mathrm{SD})$ was higher in the SH patient population (SH vs. $\mathrm{MH} ; 3.9 \pm 0.2$ vs. $3.4 \pm 0.9)$. Given the distribution of AIS ${ }_{\text {chest' }}$ $\mathrm{AIS}_{\text {chest }} 3(53.6 \%)$ was the highest component in the $\mathrm{MH}$ registry, whereas AIS $_{\text {chest }} 4(42.6 \%)$ was the highest in the $\mathrm{SH}$ group, and this was significantly different $(p<0.001)$ (Table 6). Overall, mean ISS was also significantly different between the $\mathrm{MH}(30.2 \pm 8.4)$ and the $\mathrm{SH}(42.8 \pm 10.2)$ groups, and higher ISS was determined with increasing AIS $_{\text {chest }}$ (Table 7).

In our study, hemorrhagic shock was the leading cause of trauma deaths and the mortality rate in $\mathrm{SH}$ patient population was $1 \mathrm{I} . \mathrm{I} \%(\mathrm{n}=102)$ compared to the $\mathrm{MH}$ patient population $(2.6 \% ; n=9)$. The difference in the mortality rate was statistically significant $(p<0.00 \mathrm{I})$.

\section{DISCUSSION}

This geographical location-based study reports a comparison between the data of thoracic departments of two hospitals located in different regions of Turkey. Manisa is located in Aegean region of Anatolia with a population of $\mathrm{I} .4 \mathrm{I}$ million and Şanlıurfa located in Southeast region of Anatolia with a population of 1.98 million people. Additionally, Şanlıurfa took 72.60I refugees in 2014 and it was resumed over the past four years. ${ }^{[7]}$ Thus, this article is intended to evaluate the differences of trauma patterns in a local manner and provide an overview of the thoracic trauma and associated injuries between these two hospitals.

In the present study, to exclude the minor or clinically insignificant chest injuries, AIS $_{\text {chest }} 1$, AIS $_{\text {chest }} 2$ and ISS $<16$ patients were not included in this study. The demographic data of both groups were quite different. Gender, age, mechanism of injury, associated injuries, ISS, AIS and mortality rates were significantly different between the two hospitals. Patients in the $\mathrm{SH}$ group were overwhelmingly male $(76 \%)$ in their second and third decades of life (mean age of $\mathrm{SH}: 26.4 \pm 22.4 \mathrm{yrs}$ ), but in the $\mathrm{MH}$ group, the rate of male patients were $67 \%$ and the majority of patients were in the fourth and fifth decades of life (mean age of $\mathrm{MH}: 45.6 \pm 18.3 \mathrm{yrs}$ ).

Motor vehicle crash was the predominant cause of trauma in both of our hospital registries as reported in the literature. ${ }^{[-}$
11] However, the rates of gunshot injuries (18\%), stab wound (17\%), explosion (4\%), (totally (39\%) in the SH patients population were more than twice of the $\mathrm{MH}$ registry (gunshot injuries: $5 \%$; stab wound: $9 \%$; explosion: $1 \%$; totally: $15 \%$ ). Comparing both groups in the AIS scale of all body regions, $\mathrm{AIS}_{\text {abdomen }}(4.8 \pm 0.7)$ was highest in the $\mathrm{SH}$ patient population and $\mathrm{AlSe}_{\text {xtremities }}(3.6 \pm 0.2)$ was highest in the $\mathrm{MH}$ patient population. Therefore, it can be assumed that abdominal injury was the most significant injury in the $\mathrm{SH}$ group and extremities in the $\mathrm{MH}$ patient population. Extremity injuries were generally reported to be the most common diagnosis in patients with multiple trauma. ${ }^{[2]}$ This was also in accordance with our $\mathrm{MH}$ registry. When we compared the distribution of average $\mathrm{AIS}_{\text {ches }} \mathrm{t}, \mathrm{AIS}_{\text {chest }} 4$ (42.6\%) was the highest components in the $\mathrm{SH}$ registry besides $\mathrm{AIS}_{\text {chest }} 3$ (53.6\%) was the highest component in the $\mathrm{MH}$ registry. This may be substantially attributed to the civil war in the neighbouring countries because most of the wounded were transferred from the cross-border to this hospital $(\mathrm{SH})$.

Mortality rate has been reported to vary between $6 \%$ and $19 \%$ among different studies and usually occurs within the first 24 hours. ${ }^{[13-15]}$ In our cohort, the mortality was encountered in $1 \mathrm{I} . \mathrm{I} \%$ of the $\mathrm{SH}$ patients population and it was nearly fourfold of $\mathrm{MH}$ (2.7\%) group. Mechanisms of injury, therefore, are considered to be closely related to mortality. Note that $\mathrm{SH}$ patients had a significantly higher rate of gunshot injuries and stab wounds and higher ISS.

In many reports, rib fractures were the mainly suffered chest injury occupying approximately $7 \%$ to $40 \%$ of the cases. ${ }^{[1,16-18]}$ In our study, rib fracture was also the most common thoracic injury in accordance with the literature, followed by hemotorax, pneumothorax, lung contusion, and subcutaneous emphysema. ${ }^{\left[{ }^{\prime \prime}\right]}$ Surgical stabilisation of the flail chest was performed in cases of failing to wean from the ventilator or when thoracotomy was needed for other reasons $(\mathrm{MH} \mathrm{7 \%}$ vs. $\mathrm{SH}$ $10 \%$ ). The number of rib fractures and associated injuries was reported to increase morbidity and mortality. ${ }^{[19]}$ Pulmonary contusion was the most common pulmonary parenchymal injury and was observed in $37 \%$ and $29 \%$ of the $\mathrm{MH}$ and $\mathrm{SH}$ registry. This was consistent with the literature. ${ }^{20]}$

The incidence of concomitant abdominal solid organ injury in thoracic trauma has been reported in the range of $10 \%$ and $16 \%{ }^{[3,21,22]}$ Blunt liver injury was diagnosed in 146 (16\%) of $\mathrm{SH}$ patients. The median injury severity score of these patients was 23 (range 18-36), and 38 of 146 patients (26\%) underwent laparotomy because of the haemodynamic instability. In the rest, nonoperative management was sufficient. In the $\mathrm{MH}$ cohort, the liver injury rate was II\% (42 patients), and only five patients (1I.9\%) underwent laparotomy. Nonoperative management of blunt liver injuries was reported to have a success rate of between $80-100 \%$ in haemodynamically stable patients without an acute abdomen. ${ }^{[23]}$ Spleen injury incidence was $27 \%$ in $\mathrm{SH}$ group and the splenectomy rate was 
$21 \%$, whereas spleen injury incidence was $10 \%$ in the $\mathrm{MH}$ group.

The presence of pelvic fracture has previously been related to the severity of trauma and gained acceptance as an indicator of severe injury. ${ }^{[24]}$ Giannoudishas reported that with $\mathrm{AIS}_{\text {chest }}>2,21.2 \%$ of their patients had pelvic ring injuries. ${ }^{[25]}$ In our cohort, the pelvic bone fracture was also higher and associated with 50 (14\%) of $\mathrm{MH}$ and $\mathrm{I} 39$ (15\%) of $\mathrm{SH}$ registry. Eventually, we think that the higher rates of accompanied extra-thoracic injuries significantly increased the mortality in $\mathrm{SH}$ patient population and were the leading cause of mortality.

Ten patients (I\%), in the $\mathrm{SH}$ group, underwent resuscitative thoracotomy. Two of 10 of our patients (20\%) survived. Resuscitative thoracotomy is strongly recommended in patients with no pulse but having signs of life after penetrating thoracic injury. ${ }^{[26]}$ However, no patients matched these criteria in the $\mathrm{MH}$ patients population. Urgent thoracotomy is infrequent and reported at the the rate of $3-15 \% .{ }^{[19,27]}$ Urgent thoracotomy was performed in $7 \%$ and $3 \%$ of the patients ( $\mathrm{SH}$ vs. $\mathrm{MH}$ ), which was consistent with the literature. Prehospital resuscitative thoracotomy was not performed in both of our territorial fields. Although Nevins et al. ${ }^{[28]}$ describes that indications vary by geographical locations, it has not been reported in Turkey yet.

Our study has some limitations. Firstly, both of the hospitals' data were collected retrospectively and the demographic features of the patients were quite different. Concurrently, all data were limited to the national healthcare system. Therefore, the results should be interpreted cautiously. Moreover, intensive care follow-up was not mentioned in our study.

\section{Conclusion}

These differences between $\mathrm{MH}$ and $\mathrm{SH}$ patient populations may be explained by the combat conditions ongoing in the neighbouring countries. Manisa is far from the border and have not influenced by it so far. Thus, the MH registry was compatible with the literature. However, the $\mathrm{SH}$ registry almost completely reflected the transboundary conflicts in the Middle East. Indeed, as indicated throughout this paper, this report reflects the impact of the Syrian conflict on the Turkish healthcare system. For definitive management, a multidisciplinary approach and an improved understanding of trauma at a local level are essential.

Ethics Committee Approval: Approved by the local ethics committee (date: 13.06.2019, no: 33619151/2185).

Peer-review: Internally peer-reviewed.

Authorship Contributions: Concept: S.Y.; Design: S.Y., C.M.T., D.Y.; Supervision: S.Y., C.M.T., A.H.A., A.B., M.G.P.; Resource: S.Y., D.Y., C.B.; Materials: S.Y., C.M.T., C.B.; Data: C.M.T., A.H.A., A.B., M.G.P., C.B.; Analysis: S.Y., D.Y.; Literature search: A.H.A., A.B., M.G.P., C.B.; Writing: S.Y., C.M.T.,
D.Y., A.H.A., A.B., M.G.P.; Critical revision: S.Y., C.M.T., D.Y., A.H.A., A.B., M.G.P., C.B.

Conflict of Interest: None declared.

Financial Disclosure: The authors declared that this study has received no financial support.

\section{REFERENCES}

1. Lecky FE, Bouamra O, Woodford M, Alexandrescu R, O'Brien SJ. Epidemiology of Polytrauma. In: Pape HC, Peitzman AB, Schwab CW, Giannoudis PV, editors. Damage control management in the polytrauma patient. New York, USA: Springer; 2010.p.13-24. [CrossRef]

2. Clark GC, Schecter WP, Trunkey DD. Variables affecting outcome in blunt chest trauma: flail chest vs. pulmonary contusion. J Trauma 1988;28:298-304. [CrossRef]

3. Ziegler DW, Agarwal NN. The morbidity and mortality of rib fractures. J Trauma 1994;37:975-9. [CrossRef]

4. Maslanka AM. Scoring systems and triage from the field. Emerg Med Clin North Am 1993;11:15 - 27.

5. Baker SP, O'Neill B, Haddon W Jr, Long WB. The injury severity score: a method for describing patients with multiple injuries and evaluating emergency care. J Trauma 1974;14:187-96. [CrossRef]

6. Pape HC, Lefering R, Butcher N, Peitzman A, Leenen L, Marzi I, et al. The definition of polytrauma revisited: An international consensus process and proposal of the new 'Berlin definition'.J Trauma Acute Care Surg 2014;77:780-6. [CrossRef]

7. AFAD. Available from: https://www.afad.gov.tr/30-nisan-2014-itibariyle-barinma-merkezlerimizde-220100-suriye-vatandasi-bulunmaktadir.

8. Saaiq M, Shah SA. Thoracic trauma: presentation and management outcome. J Coll Physicians Surg Pak 2008;18:230-3.

9. Lu MS, Huang YK, Liu YH, Liu HP, Kao CL. Delayed pneumothorax complicating minor rib fracture after chest trauma. Am J Emerg Med 2008;26:551-4. [CrossRef]

10. Atri M, Singh G, Kohli A. Chest trauma in Jammu region: an institutional study. Indian J Thoracic Cardiovasc Surg 2006;22:219-22. [CrossRef]

11. Narayanan R, Kumar S, Gupta A, Bansal VK, Sagar S, Singhal M, et al. An Analysis of Presentation, Pattern and Outcome of Chest Trauma Patients at an Urban Level 1 Trauma Center. Indian J Surg 2018;80:36-41.

12. Hildebrand F, Griensven MV, Garapati R, Krettek C, Pape HC. Diagnostics and scoring in blunt chest trauma. Eur J Trauma 2002;28:15767. [CrossRef]

13. Demirhan R, Onan $\mathrm{B}, \mathrm{Oz} \mathrm{K}$, Halezeroğlu S. Comprehensive analysis of 4205 patients with chest trauma: a 10 year experience. Interact Cardiovasc Surg 2009;9:450-3. [CrossRef]

14. Veysi VT, Nikolaou VS, Paliobeis C, Efstathopoulos N, Giannoudis PV. Prevalence of chest trauma, associated injuries and mortality: a level I trauma centre experience. Int Orthop 2009;33:1425-33. [CrossRef]

15. Sirmali M, Türüt H, Topçu S, Gülhan E, Yazici U, Kaya S, et al. A comprehensive analysis of traumatic rib fractures: morbidity, mortality and management. Eur J Cardiothorac Surg 2003;24:133-8. [CrossRef]

16. Sharma K, Tated SP, Hatkar AA. Study of the pattern and management of blunt chest injuries in rural setup. Int Surg J 2017;4:3482-7. [CrossRef]

17. Gabram SG, Schwartz RJ, Jacobs LM, Lawrence D, Murphy MA, Morrow JS, et al. Clinical management of blunt trauma patients with unilateral rib fractures: a randomized trial. World J Surg 1995;19:388-93.

18. Liman ST, Kuzucu A, Tastepe AI, Ulasan GN, Topcu S. Chest injury due to blunt trauma. Eur J Cardiothorac Surg 2003;23:374-8. [CrossRef]

19. Battle CE, Hutchings H, Evans PA. Expert opinion of the risk factors for 
morbidity and mortality in blunt chest wall trauma: results of a national postal questionnaire survey of Emergency Departments in the United Kingdom. Injury 2013;44:56-9. [CrossRef]

20. Cohn SM, Dubose JJ. Pulmonary contusion: an update on recent advances in clinical management. World J Surg 2010;34:1959-70. [CrossRef]

21. Rostas JW, Lively TB, Brevard SB, Simmons JD, Frotan MA, Gonzalez RP. Rib fractures and their association With solid organ injury: higher rib fractures have greater significance for solid organ injury screening. Am J Surg 2017;213:791-7. [CrossRef]

22. Poole GV Jr, Myers RT. Morbidity and mortality rates in major blunt trauma to the upper chest. AnnSurg 1981;193:70-5. [CrossRef]

23. Hommes M, Navsaria PH, Schipper IB, Krige JE, Kahn D, Nicol AJ. Management of blunt liver trauma in 134 severely injured patients. Injury 2015;46:837-42. [CrossRef]
24. Holtenius J, Bakhshayesh P, Enocson A. The pelvic fracture - Indicator of injury severity or lethal fracture?. Injury 2018;49:1568-71. [CrossRef]

25. Giannoudis PV, Grotz MR, Tzioupis C, Dinopoulos H, Wells GE, Boua$\mathrm{mra} \mathrm{O}$, et al. Prevalence of pelvic fractures, associated injuries, and mortality: the United Kingdom perspective.J Trauma 2007;63:875-83. [CrossRef]

26. Schauer SG, Hill GJ, Connor RE, Oh JS, April MD. The pediatric resuscitative thoracotomy during combat operations in Iraq and Afghanistan - A retrospective cohort study. Injury 2018;49:911-5. [CrossRef]

27. Onat S, Ulku R, Avci A, Ates G, Ozcelik C. Urgent thoracotomy for penetrating chest trauma: analysis of 158 patients of a single center. Injury 2011;42:900-4. [CrossRef]

28. Nevins EJ, Moori PL, Smith-Williams J, Bird NTE, Taylor JV, Misra N. Should pre-hospital resuscitative thoracotomy be reserved only for penetrating chest trauma?. Eur J Trauma Emerg Surg 2018;44:811-8. [CrossRef]

\section{ORİJINAL ÇALIŞMA - ÖZET}

\section{Türkiye'deki iki farklı hastanenin toraks travmalı politravma} olgularındaki verilerinin karşılaştırmalı analizi

\section{Dr. Sadık Yaldız, ${ }^{1}$ Dr. Cumhur Murat Tulay, ${ }^{1}$ Dr. Demet Yaldız, ${ }^{1}$ Dr. Ali Hızır Arpat, ${ }^{2}$ Dr. Abdülkerim Bayülgen, ${ }^{3}$ Dr. Mehmet Gökhan Pirzirenli, ${ }^{4}$ Dr. Cenk Balta ${ }^{2}$}

${ }^{1}$ Manisa Celal Bayar Üniversitesi Tıp Fakültesi, Göğüs Cerrahisi Anabilim Dalı, Manisa

2Şanlıurfa Eğitim ve Araştırma Hastanesi, Göğüs Cerrahisi Kliniği, Şanlıurfa

${ }^{3}$ Mersin Üniversitesi Tıp Fakültesi, Göğüs Cerrahisi Anabilim Dalı, Mersin

${ }^{4}$ Ondokuz Mayıs Üniversitesi Tıp Fakültesi, Göğüs Cerrahisi Anabilim Dalı, Samsun

AMAÇ: Çalışmanın amacı; biri Suriye sınıına yakın olan, ülkemizdeki iki farklı hastanenin travma birimlerinde, toraks travmalı politravma hastalarının yönetiminde ve sonuçlarında farklılık olup olmadığını değerlendirmektir.

GEREÇ VE YÖNTEM: Ocak 20I2-Ocak 2014 arasında, toraks travmalı politravma geçiren, Manisa Celal Bayar Üniversitesi Hastanesi'ndeki (MH) 348 olgu, Suriye sınıına yakın Şanlıurfa Eğitim ve Araştırma Hastanesi'ndeki (ŞH) 917 olgu ile yaş, cinsiyet, yaralanma mekanizması, eşlik eden yaralanmalar, kısaltılmış yaralanma ölçeği (AIS), yaralanma ciddiyeti skoru (ISS), tedavi yöntemleri ve mortalite açısından geriye dönük olarak analiz edildi. BULGULAR: ŞH olgularında; kesici delici alet yaralanmaları (MH; \%9'a karşı ŞH; \%।7, p<0.05), ateşli silah yaralanmaları (MH; \%5'e karşı ŞH; \%।8,

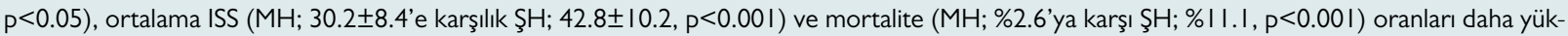

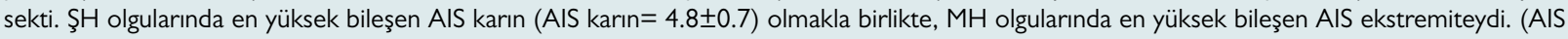
ekstremite $=3.6 \pm 0.2$ ).

TARTIŞMA: ŞH olgularındaki demografik özellikler, yaralanma mekanizmalarındaki farklııklar ve yüksek mortalite, sınırlarımızdaki ihtilaf bölgesine yakın olmanın getirdiği cerrahi zorlukları göstermekte ve yansıtmaktadır. Ülkemizde biri Suriye sınırına yakın diğeri ise sınıra uzak iki hastanenin verileri, Suriye ihtilafının Türk sağlık sistemi üzerindeki etkisini vurgulamışıı.

Anahtar sözcükler: Ek yaralanmalar; politravma; toraks travması.

Ulus Travma Acil Cerrahi Derg 2021;27(1):55-60 doi: 10.14744/tjtes.2020.80I95 